\title{
Perceptions of Foreign Language Teachers for M-Learning
}

\author{
https://doi.org/10.3991/ijet.v15i23.18799
}

\author{
Nadire Cavus $(\bowtie)$ \\ Near East University, Nicosia, Turkey \\ nadire.cavus@neu.edu.tr
}

Liudmila V. Shukshina

Plekhanov Russian University of Economics, Moscow, Russia

Oxana E. Chernova, Irina V. Telezhko

Peoples' Friendship University of Russia, Moscow, Russia

Alfia M. Ishmuradova

Kazan Federal University, Kazan, Russia

Valeria L. Zakharova,

I.M. Sechenov First Moscow Medical University, Moscow, Russia

\begin{abstract}
Educational technology is a set of systems consisting of tech savvy equipment, processes and methods for the effective and positive implementation of educational theories. Nowadays, when the internet is becoming widespread, and mobile device technologies such as smartphones and tablets have been developing rapidly, it is possible to access educational content without being connected to a place. Today, almost everyone has smartphones. Many social networks, sites, applications are available. Many studies have shown that technology is effective in the field of education. For teachers with foreign language and their perceptions of learning through the help of technology are important. In this study, it is important to determine teachers' perception levels of mobile applications that contribute to foreign language learning. The "mobile learning perception scale" developed to access the research data. Items that are mentioned in the scale are basically positive question, "absolutely disagree", "disagree", "undecided", "agree", "strongly agree". After analysing the reliability of the survey, the overall result was found as Cronbach $\alpha=0,963$. A total of 180 teachers attended from North Cyprus and Russian universities. According to the result of the research, the teachers' perception of mobile learning is high. But this rate is proportional to age. There is a difference in the findings regarding the use of mobile technology when looking at the professional seniority and age ranges. This is due to the fact that recently, technology-supported trainings have been increased and the addition of "material design courses" and "technology-supported trainings" at universities play an important role in increasing perceptions. The use of mobile
\end{abstract}


technology can be increased by providing in-service trainings to teachers with high professional experience and ages.

Keywords - Mobile learning, technology, foreign language, education, teachers

\section{Introduction}

Education is a process aimed at helping people to know, analyse and help themselves by showing what they are and to change behaviour in the individual. It is during the educational period when certain permanent behavioural changes occur in the individual's life, and these behavioural changes take place due to the individual's experiences through his journey. Therefore, a proper training is a need in well planned educational environment. In other words, it can also be called a formal education. It is referred as a planned educational activity carried out within a curriculum. Formal education is carried out through teaching. Dewey, in its broadest sense, defines education as a means of sustaining social life [22]. According to Durkheim, education is the process of awakening physical intellectual and moral states in children [28]. Children are attracted towards educational circles and technologies, and it becomes accessible to them as these features are very much independent of time and space. These can be used anytime when needed and are easy to adjust according to any location or time zone $[15,17,25]$.

Technological developments have entered the field of education, and are included in distance education and many training programs. it has started settling down by imparting information to diverse people through various modes such as modern technologies, radio signals, satellite broadcasts, network cables and many other mediums [11,29]. For example, the internet, an indispensable element of modern life, is used by the majority of today's youth for information, communication and entertainment purposes. For example, the Internet has become the indispensable part of the majority of the youth's today, and it has become the source of information, communication and entertainment purpose for them now $[25,13]$. The widespread use of technology and the constant exchange of information have revealed concepts such as distance education, e-learning, m-learning. Rapid developments in the technology and science world have put many countries in the race. Due to this race, the development of technological studies has not only been a privilege but an imperative that has to be improved continuously. In order to realize this imperative, it is necessary to benefit from educational activities by integrating technology efficiently in the curriculum [34].

Students, these days are called "digital naive" or "net generation" as mobile technologies have reached the nooks and corner of everyone's life and immensely contributed in the global communication network. This generation has seen the vast usage and growth of web services [9,23,21]. It is this generation that will become teachers who have been using computer and internet throughout their life and are well equipped with the technology. The use of information and communication technologies (ICT) for teaching purposes has become a necessity in training 
individuals who make up the information society. In the last decade, mobile learning (m-Learning) has attracted the attention of practitioners and researchers due to the rapid development of telecommunication technology and its application to mobile devices.

Of all these technological developments, mobile technology is the fastest growing technology in the high-tech industry. Keegan [16] estimates that 1.5 billion mobile phones are used by six billion people worldwide. Today, over 90 percent of people use mobile phones. Mobile phones, which are more than three times the number of personal computers, show an increase in the number of users. The penetration rate for mobile phones is more than $100 \%$ in some countries such as in Malaysia. Portable computing technology now makes mobile devices a convenient and potential tool to bridge the gap between formal and informal learning experiences [18,30], especially the learning that involves any other language [31,14].

Niazi [40] defines mobile learning through the use of technologies such as laptop, tablet, mobile phone, PDA and handheld devices in the learning and teaching process. Niazi [40] defines mobile learning as the e-learning activity carried out through the features offered by the computer and communication technologies of devices such as PDA and mobile phones, which we can carry with us in daily life. In the experimental study conducted by According to the survey data, it was seen that the students who participated in the research had high perception levels of mobile learning. In the experimental study carried out by Yavuz, Ozdemir, \& Celik [33] observed that the game application designed to measure the level of students' comprehension of English through mobile learning increased their success levels in English education. In the study conducted by Theodorou \& Meliones [27] and Garbin, Trombeta de Oliveira, Pirillo, \& Telles [7] investigated how technology should be adapted to each teaching [33].

Pre-service teachers should acquire the necessary knowledge and skills about using ICT in pre-service learning processes; they should be able to use them for different purposes, such as teaching and professional development, both during their preservice training and in their teaching life. In this context, opportunities should be created for prospective teachers to use technology in different contexts during their education. While researching about mobile learning aspects, teachers' attitudes and knowledge are very important.

\subsection{Mobile learning in foreign language teaching}

Computer is at the top of the technological devices used in language teaching. Computer assisted learning practices have been expressed with the concept of elearning (E-Learning) since 1999. It has provided students with advantages such as location, space and time-independent learning, personalized instruction and motivation towards the study. One of the most important advantages of computerassisted language learning was the possibility of learning [40]. Especially with the developing technologies, portable digital devices such as tablet computers and smart phones, which became widespread after 2000's, brought new applications and activities along with conceptual changes. Digital transformation is not just about 
technology. In addition, it is mainly provided by leadership based on 3 key elements: teamwork, startup culture and matrix management. While providing digitalization, these rules should also be considered [42].

Mobile assisted language learning and smartphone assisted language learning have been added as sub-branches of computer assisted language learning. M-learning has been added to the concept of e-learning, which has been in use since 1999 [8] [26]. In the literature review, there are many studies related to mobile supported learning of different languages. English is the leading language among these applied studies with a rate of $71.18 \%$. After English, Chinese $(\mathrm{N}=6,10.16 \%)$, Turkish $(\mathrm{N}=4,6.77 \%)$, German $(\mathrm{N}=4,6.77 \%)$, Arabic $(\mathrm{N}=2,3.38 \%)$, Persian $(\mathrm{N}=1,1.69 \%)$ education / training have been included, respectively. When applied studies were analysed, mostly positive attitudes and academic success results were reported [1,2,5]. Cevik and Koçer [34] in the domain of vocabulary; Chang and Hsu [5] in the area of reading and talking; Andujar [35] reported that they achieved positive results for the development of writing ability with portable devices.

Studies have reported successful results in learning and showed high student motivation, uninterrupted learning opportunities, visual and auditory content items as factors that are affecting students' success [1,4,5,6,19]. In short, mobile learning means "providing learning to students at anytime and anywhere using wireless internet and mobile devices, including mobile phones, personal digital assistants, smartphones and digital music players" $[3,31,20]$.

The attitude of teachers is important in the arena of mobile learning as the researches on m-learning in the field of language education shows that m-learning is an effective tool in the education of foreign language.

\section{Method}

\subsection{Research model}

In this research, the relationship between two or more variables have been examined. Relational screening model has been used to determine the above subject matter.

Scanning models are classified in different ways. Karasar [36] has divided the screening models into general screening models and case studies. General screening models are relational screening models in which only one variable is examined or individual variables are examined individually, and two or more variables are examined to determine the relationships between them.

In the study, the interests of teachers working in the high school who formed the sample regarding their perceptions of the purpose-mobile technologies adaptation, teaching perceptions of conformity in the context of mobile learning, the way of mobile learning application and communication adequacy of the tools for teaching mobile learning in language teaching were taken into consideration. Mobile learning perception levels of teachers working in high school according to their gender, age, professional experience, etc. were investigated. 


\section{$2.2 \quad$ Research group}

The research was carried out with high school teachers working in public high schools in Russia. After obtaining the necessary permissions, it was applied to high school teachers working in 280 public schools. The total return for the questionnaire with quantitative research questions was 210 . However, 20 questionnaires, which were found to be filled out among them were not taken into consideration, and 10 questionnaires were not returned. Therefore, the number of questionnaires analysed within the scope of the research is 180 .

\subsection{Data collection tool}

Personal information and mobile learning perception levels scale were used to reach the result in the research. In the personal information section, there are questions about their gender, duration of service, and their age. In the second part of the questionnaire, the mobile learning perception scale developed by Ozdamli was used to measure the perceptions of teachers working in high school about mobile learning in foreign language teaching. This scale was developed to determine teachers' perceptions of mobile learning. The scale was structured as a 3-factor and the content of the items was considered to be collected in the factors and their suitability to the theoretical structure, mainly, "harmony with purpose-mobile technologies" (8 items), "fitness for the branch" (9 items) and "communication style of mobile learning and communication competence of tools" (9 items). The scale consists of 3 factors and 26 items.

Items included in the scale for positive question items were mainly, 1 "strongly disagree", 2 "disagree", 3 "indecisive", 4 "agree", 5 "absolutely agree". In the negative question items, the listed degrees were 1 "strongly agree", 2 "agree", 3 "indecisive", 4 "disagree", 5 "absolutely disagree". Necessary permissions were obtained from Fezile Ozdamli for the use of the scale.

\subsection{Data analysis}

All the data collected with scale forms were encoded and entered into the computer, and tables were explained and interpreted within the given framework of the general purpose and sub-objectives of the research area. SPSS 20.0 program was used for the necessary statistical solutions. In the analysis of the data; in descriptive statistics, frequency (f), percentage (\%), arithmetic mean (X) and standard deviation (s), variance analysis were used in one-factor comparisons. The data obtained with the applied questionnaire were analysed by using $\mathrm{t}$-test and one-factor variance (One-Way ANOVA) analysis techniques, and explained by tabulating.

\subsection{Evaluation of the suitability of the data for factor analysis}

The data obtained from the study group is suitable for exploratory factor analysis explained by Kaiser-Meyer-Olkin (KMO) and Barlett test [37,38]. The high value of 
Kaiser-Meyer-Olkin means that each variable of the scale can be perfectly predicted by other variables. If the values are zero or close to zero, no interpretation based on these values can be made, since there is a distribution in the correlation distribution. As a result of the Kaiser-Meyer-Olkin test, it is interpreted that factor analysis cannot be continued if the value is less than 0.50 [37].

Table 1. Factor Analysis

\begin{tabular}{|c|c|c|c|c|c|c|c|c|c|}
\hline & \multicolumn{2}{|c|}{ Initial Eigenvalues } & \multirow[b]{2}{*}{$\begin{array}{c}\text { Cumulative } \\
\%\end{array}$} & \multicolumn{3}{|c|}{$\begin{array}{c}\begin{array}{c}\text { Extraction sum of Squared } \\
\text { Loading }\end{array} \\
\end{array}$} & \multicolumn{3}{|c|}{$\begin{array}{c}\text { Rotation Sum of Squared } \\
\text { Loadings } \\
\end{array}$} \\
\hline$\vec{t}$ & Total & $\begin{array}{c}\% \text { OF } \\
\text { ARIANCE }\end{array}$ & & Total & \begin{tabular}{|c|}
$\%$ \\
variance
\end{tabular} & $\begin{array}{c}\text { Cumulative } \\
\%\end{array}$ & Total & $\begin{array}{c}\% \\
\text { variance }\end{array}$ & $\begin{array}{c}\text { Cumulative } \\
\%\end{array}$ \\
\hline 1 & & & & & & & & & \\
\hline 2 & & & & & & & & & \\
\hline 3 & 2.985 & 11.056 & 97.082 & 2.985 & 11.056 & 97.082 & 3.004 & 11.126 & 97.082 \\
\hline
\end{tabular}

In this research, two factors were discussed, mainly, that the scale used in the research has 3 factors. And while the first and second factors are significant, the third factor is meaningless.

\section{Results and Discussion}

\subsection{Demographic features of the participants}

Frequency (f) and percentile (\%) distributions of the gender of the teachers constituting the sample group of the research were given in Table 2.

Table 2. Distribution of teachers by gender

\begin{tabular}{|l|c|}
\hline & F \\
\hline Woman & 99 \\
\hline Men & 81 \\
\hline
\end{tabular}

When the distribution of teachers according to their gender was examined, it was seen that female teachers were more in number.

Table 3. Distribution of teachers by age

\begin{tabular}{|l|c|}
\hline & F \\
\hline 28 and under & 57 \\
\hline 29 and 35 & 55 \\
\hline 36 and 45 & 42 \\
\hline 46 and above & 26 \\
\hline
\end{tabular}

When the teachers were examined according to their age, it was seen that most were in the age group of 28 and below. 
Table 4. Distribution of teachers by duration of service

\begin{tabular}{|l|c|}
\hline & F \\
\hline Between 1 and 6 years & 78 \\
\hline Between 7 and 15years & 59 \\
\hline 16 year and over & 43 \\
\hline
\end{tabular}

The teachers were found to be between the years 1 to 6 on an examination on the basis of professional seniority where any finding of age was almost equivalent to the professional seniority.

\subsection{Gender}

In order to understand that there is no significant difference in gender in the study, ANOVA test was performed.

Table 5. Factor of gender

\begin{tabular}{|l|l|c|c|c|c|c|}
\hline \multicolumn{2}{|c|}{} & Sum of Squares & df & M & F & Sig. \\
\hline \multirow{4}{*}{ Factor 1 } & Between Groups & .110 & 1 & .110 & .109 & .742 \\
\cline { 2 - 7 } & Within Groups & 177.890 & 177 & 1.005 & & \\
\cline { 2 - 7 } & Total & 178.000 & 178 & & & \\
\hline \multirow{3}{*}{ Factor 2 } & Between Groups & 7.734 & 177 & 7.734 & 8.039 & .005 \\
\cline { 2 - 7 } & Within Groups & 170.266 & 178 & & & \\
\cline { 2 - 7 } & Total & 178.000 & & & & \\
\hline
\end{tabular}

Anova was used to see if there was a significant difference when compared to the gender. There is a significant difference between the factor 2 by age. In the study, there was no significant difference in terms of " Purpose-Mobile Technologies Compliance ( 8 items). There is significant difference according to the "Branch compatibility (9 items)" factor by gender. Man have higher perceptions in the field of "Branch compliance" than women.

\subsection{Age}

Table 6. Factor of age

\begin{tabular}{|c|l|c|c|c|c|c|}
\hline \multicolumn{2}{|c|}{} & Sum of Squares & df & M & F & Sig. \\
\hline \multirow{3}{*}{ Factor 1 } & Between Groups & 12.135 & 3 & 4.045 & 4.268 & .006 \\
\cline { 2 - 7 } & Within Groups & 165.865 & 175 & .948 & & \\
\cline { 2 - 7 } & Total & 178.000 & 178 & & & \\
\hline \multirow{3}{*}{ Factor 2 } & Between Groups & .972 & 3 & .324 & .320 & .811 \\
\cline { 2 - 7 } & Within Groups & 177.028 & 175 & 1.012 & & \\
\cline { 2 - 7 } & Total & 178.000 & 178 & & & \\
\hline
\end{tabular}

ANOVA was used to see if there was a significant difference when compared to the ages. There is a significant difference between the factor 1 by age. In the study, 
there was no significant difference in terms of "Purpose-Mobile Technologies Compliance ( 8 items)". There is no significant difference according to the "Branch compatibility ( 9 items)" factor by age. If we look at the distribution by age, the perception of those who are younger is higher in the "Purpose-Mobile Technologies Compliance" field. However, when we look at the "Branch compliance" factor, we see that age does not make a difference.

\subsection{Service of duration}

Table 7. Factor of Service of Duration

\begin{tabular}{|c|c|c|c|c|c|c|}
\hline & & Sum of Squares & Df & Mean Square & $\mathbf{F}$ & Sig. \\
\hline \multirow{3}{*}{ Factor 1} & Between Groups & 5.790 & 2 & 2.895 & 2.959 & .054 \\
\hline & Within Groups & 172.210 & 176 & .978 & & \\
\hline & Total & 178.000 & 178 & & & \\
\hline \multirow{3}{*}{ Factor 2} & Between Groups & .789 & 2 & .394 & .392 & .677 \\
\hline & Within Groups & 177.211 & 176 & 1.007 & & \\
\hline & Total & 178.000 & 178 & & & \\
\hline
\end{tabular}

Anova was used to see if there was a significant difference when compared to the Service of Duration. There is a significant difference between the factor 1 by age. A significant difference was found between the factor 1 by age when compared to the service of duration on the usage of ANOVA. In the study, there was no significant difference in terms of "Purpose-Mobile Technologies Compliance (8 items)" or according to the "Branch compatibility ( 9 items)" factor by service of duration. If we look at the distribution by service of duration, the perception of those who are younger is higher in the "Purpose-Mobile Technologies Compliance" field. However, when we look at the "Branch compliance" factor, we see that age does not make a difference. Yavuz, Ozdemir, \& Celik [33] used gamification technology in foreign language teaching and measured the effectiveness in teaching with mobile powered tools. In this research, the result is consistent with our study. Teachers' perceptions about mobile supported technologies are high. Yavas Celik \& Yavuz [33] Academics questioned the effect of talent on success and over time developed many language aptitude tests because success and achievement prediction in aptitude measurement will mean saving time in language learning. In addition, language learning skills have started to be compared with other individual differences (IDs) with the changing talent understanding in recent years. These studies aim to increase students' success by designing instructions based on their abilities and other identities. Therefore, this study aimed to find the relationship between the language proficiency of Turkish EFL students, the use of self-reported strategy and language success in order to see the enhancement of language proficiency with its strategic use and success. The results showed that language skills affect the success of foreign language learning. 


\section{Conclusion}

In the research, it was concluded that women are more efficient teachers than men. Considering the age ranges, it was concluded that there are more teachers in the age range of 29 and 35. Professional seniority is relatively equivalent in proportion to age If we look at the number of the teachers according to their gender, we will notice a significant difference by a factor of 2 by age. In the study, there is no significant difference in terms of "Objectives-Mobile Technologies Compliance (8 items)" but we found a significant difference by gender according to the "Branch compatibility (9 items)" factor. also called "Branch compliance" for men. Anova was used to see if there was a significant difference by age. There is a significant difference between factor 1 and age. Although it can be noticed that the perception of the youth is higher in the "Objectives-Mobile Technologies Compliance area,". However, when we look at the branch compliance factor, we see that age does not make a difference. Anova was used to see if there was a significant difference compared to the Duration Service. There is a significant difference between factor 1 and age. In the study, there was no significant difference in terms of "Compliance with Purpose-Mobile Technologies (8 questions)", but there was no significant difference in terms of service time according to the given "Service time (9 questions)" factor. If we examine the distribution by time service, perception is higher in the field of "Purpose-Compliance with Mobile Technologies."

\section{$5 \quad$ Suggestions}

As a result of the research, when the perceptions of teachers teaching foreign languages about the use of mobile technology were examined, it was seen that there was a positive result. It is pleasing that perceptions are high in relation to mobile technologies. However, although their perceptions about mobile technology are high, their usage rates are low. Informative sessions can be arranged for teaching the use of mobile technology. In-service trainings can be offered and practices of mobile learning. can be increased for middle-aged teachers.

\section{$6 \quad$ References}

[1] Amer, M. (2014). Language learners' usage of a mobile learning application for learning idioms and collocations. Calico Journal, 31(3): 285-302. https://doi.org/10.11139/cj.31.3. $\underline{285-302}$

[2] Berns, A., Isla-Montes, J. L., Palomo-Duarte, M., \& Dodero, J. M. (2016). Motivation, students' needs and learning outcomes: a hybrid game-based app for enhanced language learning. SpringerPlus, 5(1): 1305. https://doi.org/10.1186/s40064-016-2971-1

[3] Cavus, N., \& Uzunboylu, H. (2009). Improving critical thinking skills in mobile learning [Electronic Version]. Procedia - Social and Behavioral Sciences, 1(2): 434-438. https://doi. org/10.1016/j.sbspro.2009.01.078 
[4] [Chai, C. S., Wong, L. H., \& King, R. B. (2016). Surveying and modeling students' motivation and learning strategies for mobile-assisted seamless Chinese language learning. Journal of Educational Technology \& Society, 19(3): 170.

[5] Chen, C. M., Hsu, S. H., Li, Y. L., \& Peng, C. J. (2006, October). Personalized intelligent m-learning system for supporting effective English learning. In 2006 IEEE International Conference on Systems, Man and Cybernetics (Vol. 6, pp. 4898-4903). IEEE. https://doi. org/10.1109/icsmc.2006.385081

[6] Foomani, E. M., \& Hedayati, M. (2016). A seamless learning design for mobile assisted language learning: An Iranian context. English Language Teaching, 9(5): 206-213. https:// doi.org/10.5539/elt.v9n5p206

[7] Garbin, M., Trombeta de Oliveira, E., Pirillo, N., \& Telles, S. (2020). Pedagogical practices based on areas of knowledge: Reflections on the technology use. New Trends and Issues Proceedings on Humanities and Social Sciences, 7(1): 134-141. https://doi.org/10.1 8844/prosoc.v7i1.4877

[8] Georgiev, T., Georgieva, E., \& Smrikarov, A. (2004). M-learning - A New Stage of ELearning. International Conference on Computer Systems and TechnologiesCompSysTech, 4(28): 1-5. https://doi.org/10.1145/1050330.1050437

[9] Gokbulut, B. (2020). The effect of Mentimeter and Kahoot applications on university students' e-learning. World Journal on Educational Technology: Current Issues, 12(2): 107-116. https://doi.org/10.18844/wjet.v12i2.4814

[10] Göçer, A., \& Moğul, S. (2011). Türkçenin Yabancı Dil Olarak Öğretimi ile İlgili Çalışmalara Genel Bir bakış. International Periodical for The Languages, Terature and History of Turkish or Turkic, 6(3): 797-810.

[11] Gülbahar, Y., 2009. E-öğrenme. Ankara: Pegem

[12] Inaltekin, T. (2020). Examining secondary students' perceptions of the technology-based learning and teaching in science courses. World Journal on Educational Technology: Current Issues, 12(2): 71-83. https://doi.org/10.18844/wjet.v12i2.4628

[13] Jitgarun, K., \& Tongsakul, A. (2009). Virtual-based training and critical thinking in higher-level education. Cypriot Journal of Educational Sciences, 4(7): 02-14.

[14] Joudi, N. (2019). Gender leadership styles and linguistic practices: The case of Lebanese International University coordinators. International Journal of Innovative Research in Education, 6(2): 47-61. https://doi.org/10.18844/ijire.v6i2.4362

[15] Kay, R. (2020). Analyzing the use of mathematics apps in elementary school classrooms. Contemporary Educational Researches Journal, 10(2): 68-78. https://doi.org/10.18844/cerj . $\mathrm{v} 10 \mathrm{i} 2.4732$

[16] Keegan, D. (2005). "The incorporation of mobile learning into mainstream education and training". In Mobile Learning 2005, Edited by: Isias, P., Borg, C. and Bonanno, P. 198202. Lisbon: IADIS.

[17] Harrell, P. E., \& Harris, M. (2006). Teacher preparation without boundaries: A two-year study of an online teacher certification program. Journal of Technology and Teacher Education, 14(4): 755-774.

[18] Kolb, L. 2006. From toy to tool: Audioblogging with cell phone. Learning \& Leading with Technology, 34: 16-20

[19] Liu, J., Yu, S., \& Ran, M. (2008, March). Research on the communicative mobile English learning model. In Fifth IEEE International Conference on Wireless, Mobile, and Ubiquitous Technology in Education (wmute 2008) (pp. 60-64). IEEE. https://doi.org/10. $\underline{1109 / \text { wmute. } 2008.26}$ 
[20] Marzano, G., Usca, S., \& Lubkina, V. (2020). A multidimensional approach to support training activities in the digital era. New Trends and Issues Proceedings on Humanities and Social Sciences, 7(1): 10-19. https://doi.org/10.18844/prosoc.v7i1.4896

[21] Oblinger, D. (2003). Boomers, gen-Xers and millennials: Understanding the new students". In Educause Review.

[22] Ozcan, D., \& Merdan, F. (2020). The effectiveness of video modelling for teaching daily life skills to children with autism spectrum disorder. International Journal of Learning and Teaching, 12(1): 42-54. https://doi.org/10.18844/ijlt.v12i1.4560

[23] Prensky, M. 2007. Digital game-based learning, St. Paul, MN: Paragon House.

[24] Sarıçoban, A., \& Özturan, T. (2012). Vocabulary learning on move: An investigation of mobile assisted vocabulary learning effect over students' success and attitude, The Journal of Ekev Akademi, 17(54), 213-224.

[25] Ozdamli, F., \& Uzunboylu, H. (2015). M-learning adequacy and perceptions of students and teachers in secondary schools. British Journal of Educational Technology, 46(1): 159172. https://doi.org/10.1111/bjet.12136

[26] Sharples, M. (2000). The design of personal mobile technologies for lifelong learning. Computers \& education, 34(3-4): 177-193. https://doi.org/10.1016/s0360-1315(99)00044$\underline{5}$

[27] Theodorou, P., \& Meliones, A. (2019). Developing apps for people with sensory disabilities, and implications for technology acceptance models. Global Journal of Information Technology: Emerging Technologies, 9(2): 33-40. https://doi.org/10.18844/g jit.v9i2.4431

[28] Ugurlu, N. B. (2013). What they think about democracy? sample of 8 th grade American and Turkish students.

[29] Christensen, R., Knezek, G., Tyler-Wood, T., \& Gibson, D. (2011). SimSchool: An online dynamic simulator for enhancing teacher preparation. International Journal of Learning Technology, 6(2): 201-220. https://doi.org/10.1504/ijlt.2011.042649

[30] Dirin, A., Laine, T.., Alamäki, A., (2018). Managing Emotional Requirements in a Context- Aware Mobile Application for Tourists. Int. J. Interact. Mob. Technol. 12, 177. https://doi.org/10.3991/ijim.v12i2.7933

[31] Wang, Q. 2008. A generic model for guiding the integration of ICT into teaching and learning. Innovations in Education and Teaching International, 45: 411-419. https://doi. org/10.1080/14703290802377307

[32] Yamada, M., Kitamura, S., Shimada, N., Utashiro, T., Shigeta, K., Yamaguchi, E. and Nakahara, J. (2011). Development and evaluation of English listening study materials for business people who use mobile devices: A case study. CALICO Journal, 29(1): 44-66. https://doi.org/10.11139/cj.29.1.44-66

[33] Yavas Celik, G., \& Yavuz, F. (2020). The role of the language aptitude and self-reported strategy use on the achievement of EFL learners. Global Journal of Foreign Language Teaching, 10(1): 32-48. https://doi.org/10.18844/gjflt.v10i1.4412

[34] Kissau, S. (2015). Type of instructional delivery and second language teacher candidate performance: online versus face-to-face. Computer Assisted Language Learning, 28(6): 513-531. https://doi.org/10.1080/09588221.2014.881389

[35] Muniasamy, A., Alasiry, A. (2020). Deep Learning: The Impact on Future eLearning. International Journal of Emerging Technologies in Learning (iJET), 15(1): 188. https://doi. org/10.3991/ijet.v15i01.11435

[36] Andujar, A. (2016). Benefits of mobile instant messaging to develop ESL writing. System, 62, 63-76. https://doi.org/10.1016/j.system.2016.07.004

[37] Karasar, N. (2002). Scientific research methodology. Ankara: Nobel Publishing. 
[38] Çokluk, Ö., Şekercioğlu, G., \& Büyüköztürk, Ş. (2012). Sosyal bilimler için çok değişkenli istatistik: SPSS ve LISREL uygulamaları (Vol. 2). Ankara: Pegem Akademi. https://doi. org/10.14527/9789756802335

[39] Poltisinsskaya, E., Lizunkov, V. \& Ergunova, O. (2019). Organization of Student Project Based Activities through Individual Learning Routes. International Journal of Emerging Technologies in Learning, 14(11): 186-193. https://doi.org/10.3991/ijet.v14i11.10312

[40] Niazi, R. (2007). Design and Implementation of a Device-Independent Platform for Mobile Learning. ProQuest.

[41] Lai, C. S., Peng, Z. L., \& Zhang, S. (2006). U.S. Patent Application No. 29/209,612.

[42] Salvetti, F. \& Bertagni, B. (2020). Leadership 5.0: An Agile Mindset for a Digital Future. International Journal of Advanced Corporate Learning (iJAC), 13(2): 57-66. https://doi. org/10.3991/ijac.v13i2.17033

\section{$7 \quad$ Authors}

Nadire Cavus is a lecturer at the Department of Computer Information Systems, Near East University, Cyprus. Her interests are technology, mobile learning, virtual learning environments, and distant learning. Email: nadire.cavus@neu.edu.tr

Liudmila V. Shukshina is a Doctor of Philosophy, Professor of the Department of Psychology at Plekhanov Russian University of Economics (36 Stremyanny Pereulok, 115093, Moscow, Russia). Her main scientific and professional interests are related to personality psychology, social philosophy and social psychology. She actively studies the socio-psychological aspects of the formation of professional thinking and the phenomenon of social illusions. Email: liudmila.shukshina@yandex.ru

Oxana E. Chernova is $\mathrm{PhD}$ in Education, Associate Professor of the Chair of Foreign Languages at Peoples' Friendship University of Russia (RUDN University) (6, Miklukho-Maklyaya street, 117198, Moscow, Russia) has been working in teaching foreign languages, particularly ESP, to university students for more than 20 years. The author of more than 40 publications on developing learner autonomy, problems of teaching translation and ways to tackle them at modern university, meeting the challenge of translation teaching in contemporary system of higher education, training of translators of vocationally-oriented texts of engineering professions, application of LMSs in training would-be translators, etc. E-mail: oxanac@mail.ru

Irina V. Telezhko is $\mathrm{PhD}$ in Education, Associate Professor of Russian Language Department at Peoples' Friendship University of Russia (RUDN University) (6, Miklukho-Maklyaya street, 117198, Moscow, Russia) has been teaching foreign languages as well as Russian as a foreign language for special purposes to foreign students for more than 25 years. The author of more than 50 publications on the methods and techniques of teaching foreign languages in the IHL. Research interests: professional activity of a translator, theory and practice of professionally oriented translation, intercultural communication, linguoculturology. E-mail: Irina-Telezhko $@$ mail.ru

Alfia M. Ishmuradova is $\mathrm{PhD}$ in Pedagogy, Associate Professor of the Department of Foreign Languages at Kazan Federal University in Nabereznye Chelny 
Institute (branch) of Kazan (Volga) Federal University (18 Kremlyovskaya Street, 420000, Kazan, Russia). She has a large number of articles included in international citation databases, is a productive author. Her research interests for the last decade have been connected with project work and as well as problems of teaching English to students of non-linguistic universities. She has more 30 articles published in international journals and conferences materials. E-mail: alfiaishmuradova@mail.ru

Valeria L. Zakharova is $\mathrm{PhD}$ in Medicine, Lecturer of the Department of Urgent and Outpatient Therapy at I.M. Sechenov First Moscow Medical University (Sechenov University) (8 Trubetskaya Street, 119991, Moscow, Russia). She has more than 70 published articles in Russian and International journals. Her research interests are connected with health care education. E-mail: zkvaleria@mail.ru

Article submitted 2020-09-13. Resubmitted 2020-10-10. Final acceptance 2020-10-10. Final version published as submitted by the authors. 